with literature data, and also taking into account the fact that all the quinones known for sage are phenanthrene derivatives, we have established that the quinone isolated from the roots of Salvia nemorosa $\mathrm{L}$. is 7-acetoxyroyleanone, which has been obtained previously [2] from the roots of Inula royleana together with royleanone and 6, 7-dehydroroyleanone.

\title{
REFERENCES
}

1. Flora of the USSR [in Russian], Moscow-Leningrad, vol, 21, 1954.

2. O, E. Edwards, G. Feniak, and M. Los, Canad. J. Chem., 40, no. 8, 1540, 1962.

5 March 1969

All-Union Scientific-Research Institute for

Medicinal Plants

\section{LACTONES OF THE FRUIT OF XANTHOGALUM PURPURASCENS}

UDC 547.814

\section{A. I. Sokollova and G. K. Nikonov}

Khimiya Prirodnykh Soedinenii, Vol. 5, No. 4, pp. 317-318, 1969

From the fruit of Xanthogalum purpurascens Lallem. collected in the region of Dombaiskaya polyana (Northern Caucasus) we have established the presence of $7.4 \%$ of lactones consisting of a mixture of four components with $R_{f} 0.92$, $0.75,0.55$ (traces), and 6.00 (traces). The mobile system was $n$-hexane-benzene-methanol $(5: 4: 1)$ and the stationary phase a $10 \%$ solution of formamide in methanol.

By chromatography on acid alumina we isolated two lactones: $\mathrm{C}_{19} \mathrm{H}_{20} \mathrm{O}_{5}, \mathrm{mp} 82-83^{\circ} \mathrm{C},[\alpha]_{\mathrm{D}}^{20}-129.3^{\circ}\left(\mathrm{CH}{ }_{3} \mathrm{C} 1\right)$, $\mathrm{R}_{f} 0.92(\mathrm{~A})$; and $\mathrm{C}_{16} \mathrm{H}_{14} \mathrm{O}_{5}$, mp $147-148.5^{\circ} \mathrm{C}, \mathrm{R}_{f} 0.75$ (B), and also a substance $\mathrm{C}_{29} \mathrm{H}_{50} \mathrm{O}$, mp $139-140^{\circ} \mathrm{C}(\mathrm{C})$.

Lactone A had a UV spectrum characteristic for a dihydropyrano- or dihydrofurocoumarin with a small peak in the $259 \mathrm{~m} \mu$ region $\left(\lambda_{\max } 220,258,329, \mathrm{~m} \mu ; \log \varepsilon 4.8,3.76,4.24\right)$. The UV spectrum of the lactone had absorption bands of of a lactone carbonyl $\left(1728 \mathrm{~cm}^{-1}\right)$, of the $-\mathrm{C}=\mathrm{C}-$ bond of an unsaturated $\alpha$-pyrone $\left(1630 \mathrm{~cm}^{-1}\right)$, of a $-\mathrm{C}=\mathrm{C}-\mathrm{bond}$ of an aromatic nucleus $\left(1570,1495 \mathrm{~cm}^{-1}\right)$, and of the stretching vibrations of an $\alpha$-pyran ring $\left(1393,1350 \mathrm{~cm}^{-1}\right)$. The broad carbonyl band and also the change in $\mathrm{R}_{f}$ as a result of treatment with alkali showed the presence of an acyl residue in its molecule. Hydrolytic cleavage with alkali gave a hydroxylactone $\mathrm{C}_{14} \mathrm{H}_{14} \mathrm{O}_{4}, \mathrm{mp} 183-183.5^{\circ} \mathrm{C}$ (from ether), $[\alpha]_{\mathrm{D}}^{20}-6.8^{\circ}$, and angelic acid.

On the basis of mixed melting points and the physicochemical constants and IR spectra of the substance and the product of its hydrolysis, lactone $A$ was identified as agasyllin ( $3^{\circ}$-angeloyloxy- $3^{\circ}, 4^{\circ}$-dihydropyrano- $\left.5^{\circ}, 6^{\circ}: 6,7-c o u m a r i n\right)$, which has been isolated previously in the crystalline state from Agasyllis latifolia (Bieb.) Boiss [1] and also in the form of an oil from Seseli libanotis (L.) Koch [2]. From its constants, IR spectrum, and a mixed melting point, lactone B was identified as isooxypeucedanin.

By its chemical properties (Liebermann-Burchard reaction for sterols), IR spectrum, and a mixed melting point, substance $C$ was identified as $B$-sitosterol.

\section{REFERENCES}

1. G. K. Nikonov, G. Yu. Pek, and V. V. Vandyshev, KhPS [Chemistry of Natural Compounds], 5, 119, 1969.

2. J. Lemmich, E. Lemmich, and B. E. Nielsen, Acta Chem. Scand., 20, 1966. 